\title{
Arterial Oxygen Studies in Premature Newborns with and without Mild Respiratory Disorders
}

\author{
MARCELLO M. ORZALESI, MODESTO MENDICINI, GIOVANNI BUCCI, \\ ANTONIO SCALAMANDRE, and PIER GIORGIO SAVIGNONI \\ From the Department of Paediatrics, University of Rome Medical School, Rome, Italy
}

Arterial oxygen studies in full-term infants at various ages have been made by numerous authors (Stahlman, 1957; Weisbrot, James, Prince, Holaday, and Apgar, 1958; Graham, Koeff, Tsao, Sloan, and Wilson, 1959; Reardon, Baumann, and Hadded, 1960; Oliver, Demis, and Bates, 1961; Nelson, Prod'hom, Cherry, Lipsitz, and Smith, 1963). Few similar studies have been performed on premature infants (Graham, Reardon, Wilson, Tsao, and Baumann, 1950; Prod'hom, Levison, Cherry, Drorbaugh, Hubbell, and Smith, 1964). In 1965 Moss, Emmanouilides, Rettori, Higashimo, and Adams published data from premature infants in the first 72 hours of life, showing that 'normal' prematures had lower arterial oxygen tensions than adults, and that this difference was accentuated in prematures with 'mild respiratory distress': the criteria for classifying the babies as 'normal' were not explained in detail and the type and the severity of respiratory distress were not defined clearly. Furthermore, no studies were performed in infants of more than 72 hours.

The present paper provides data on arterial blood gases in normal premature infants from 3 hours to 40 days of age. The criteria for normality were based on clinical grounds and on chest $x$-ray findings. In addition, data from premature infants with tachypnoea and with transient mild respiratory distress, but without $x$-ray changes suggestive of pneumonia or hyaline membrane disease (Iannaccone, Bucci, and Savignoni, 1965), are also presented.

\section{Material and Methods}

The study includes 59 premature infants admitted between December 1964 and February 1966, and ranging in age from 3 hours to 40 days; the birthweight ranged between 1130 and $2480 \mathrm{~g}$., and the gestational age from 28 to 40 weeks. All were admitted to the premature unit within 24 hours of birth. A physical examina-

Received August 25, 1966. tion and two antero-posterior chest $x$-ray films were taken on admission on each baby; Silverman's retraction score (Silverman and Andersen, 1956), the respiratory rate, skin colour, heart rate, and other physical findings were recorded every 3 hours during the first two days of life (or longer if abnormal) and less frequently thereafter. The chest $x$-ray films were evaluated separately by the radiologist and were graded according to previously published criteria (Iannaccone et al., 1965). On the basis of the clinical and radiological findings the infants were divided into 3 groups (Table I).

The first group included 40 infants with birthweights between 1260 and 2480 g., who were both clinically and radiologically normal (i.e. Silverman's score $\leqslant 2$, respiratory rate $\leqslant 65 /$ min., skin colour normal, cardiac murmurs absent, and, on $x$-ray films, absence of vascular engorgement, atelectasis, emphysema, air bronchograms, or fine granularity).

The second group comprised 14 infants with birthweights between 1130 and 2260 g., who had respiratory rates above $65 / \mathrm{min}$. for at least 24 hours and no other signs of respiratory or cardiac disorders (Silverman's score always $\leqslant 2$ ). The chest $x$-ray films were normal in all except 2 babies in whom mild patchy atelectasis was present.

The third group comprised 5 infants with birthweights between 1790 and 2310 g., who had Silverman's scores of 3 in the first 24 hours of life and respiratory rates above $60 /$ min. during the first 48 hours. The chest $x$-ray films showed mild patchy atelectasis in 2 babies and were normal in 3.

None of the infants studied had the radiological features of hyaline membrane disease (decreased translucency, reticulo-granular pattern, and air bronchogram) or pneumonia (coarse nodularity, severe patchy atelectasis, and emphysema), and all recovered and survived. Respiratory distress in infants of the second and third group was always mild, so that, on clinical grounds, it was judged safe to study them while breathing room air.

Thirteen normal adults were also studied and served as controls.

Using the techniques described in previous papers (Scalamandrè, Bucci, Orzalesi, Mendicini and Savignoni, 1966; Bucci, Scalamandrè, Savignoni, Orzalesi, and 
TABLE I

Number of Subjects, Average Birthweight, Gestational Age, Average Silverman's Score, and Respiratory Rate at Different Ages, in the 3 Groups of Prematures Studied

\begin{tabular}{|c|c|c|c|c|c|c|c|c|c|c|c|c|c|c|}
\hline \multirow[b]{2}{*}{ Group } & & \multirow[b]{2}{*}{ No. } & \multirow[b]{2}{*}{$\begin{array}{c}\text { Birthweight } \\
\text { (kg.) }\end{array}$} & \multirow{2}{*}{$\begin{array}{c}\text { Gesta- } \\
\text { tional } \\
\text { Age } \\
\text { (wk.) }\end{array}$} & \multicolumn{2}{|c|}{ 1-6 Hours } & \multicolumn{2}{|c|}{ 7-24 Hours } & \multicolumn{2}{|c|}{ 25-48 Hours } & \multicolumn{2}{|c|}{ 49-72 Hours } & \multicolumn{2}{|c|}{ 73-96 Hours } \\
\hline & & & & & Score & $\begin{array}{l}\text { Resp- } \\
\text { iratory } \\
\text { Rate }\end{array}$ & Score & $\begin{array}{c}\text { Resp- } \\
\text { iratory } \\
\text { Rate }\end{array}$ & Score & $\begin{array}{c}\text { Resp- } \\
\text { iratory } \\
\text { Rate }\end{array}$ & Score & $\begin{array}{l}\text { Resp- } \\
\text { iratory } \\
\text { Rate }\end{array}$ & Score & $\begin{array}{l}\text { Resp- } \\
\text { iratory } \\
\text { Rate }\end{array}$ \\
\hline & $\cdots$ & 40 & $\begin{array}{c}1 \cdot 76 \\
(1 \cdot 26-2 \cdot 48)\end{array}$ & $\begin{array}{c}34 \cdot 5 \\
(28-40)\end{array}$ & 0.8 & 56 & 0.6 & 52 & 0.5 & 51 & $0 \cdot 2$ & 48 & $0 \cdot 2$ & 46 \\
\hline Tachypnoea & $\cdots$ & 14 & $(1 \cdot 13-2 \cdot 26)$ & $\begin{array}{c}33 \cdot 6 \\
(31-38)\end{array}$ & $1 \cdot 2$ & 71 & $1 \cdot 4$ & 69 & $1 \cdot 1$ & 66 & 0.6 & 58 & $0 \cdot 4$ & 54 \\
\hline Mild RDS & $\ldots$ & 5 & $(1 \cdot 79-2 \cdot 31)$ & $(32-37)$ & - & 一 & $3 \cdot 0$ & 67 & $2 \cdot 4$ & 64 & $1 \cdot 0$ & 57 & $0 \cdot 8$ & 55 \\
\hline
\end{tabular}

Mendicini, 1966), 104 samples of arterial blood were taken from the radial artery, 22 from the temporal artery, and 8 from the umbilical artery. The infants breathed room air and remained generally quiet during the procedure.

All blood analyses were performed within 10 minutes of sampling. Arterial $\mathrm{pH}$ and base excess (BE) were measured at $37 \cdot 5^{\circ} \mathrm{C}$., using the Astrup apparatus* (Astrup, Jörgensen, Siggaard Andersen, and Engel, 1960) and carbon-dioxide tension $\left(\mathrm{P}_{\mathrm{a}} \mathrm{CO}_{2}\right)$ was derived from the Siggaard Andersen nomogram, after correcting for the amount of unsaturated haemoglobin (Siggaard Andersen, 1962). Arterial oxygen tension $\left(\mathrm{P}_{\mathrm{a}} \mathrm{O}_{2}\right)$ was measured at $37 \cdot 5^{\circ} \mathrm{C}$. with a Clark electrode ${ }^{\star}$, and oxygen saturation $\left(\mathrm{S}_{\mathrm{a}} \mathrm{O}_{2}\right)$ was calculated from the $\mathrm{P}_{\mathrm{a}} \mathrm{O}_{2}$ and $p \mathrm{H}$, using the foetal blood $\mathrm{O}_{2}$ dissociation curves at various $p \mathrm{Hs}$, obtained by combining the data of Edwards and Ross (1959) and Nelson, Prod'hom, Cherry, and Smith (1964); $\mathrm{S}_{\mathrm{a}} \mathrm{O}_{2}$ in adults was derived from standard published curves (Rahn and Fenn, 1955). Haemoglobin concentration was measured with the cyanmethaemoglobin method.

Almost all determinations were carried out in duplicate, and all values of $p \mathrm{H}, \mathrm{P}_{\mathrm{a}} \mathrm{CO}_{2}$, and $\mathrm{P}_{\mathrm{a}} \mathrm{O}_{2}$ were corrected for the temperature of the babies using published correction factors (Bradley, Stupfel, and Severinghaus, 1956; Adamsons, Daniel, Gandy, and James, 1964).

Venous admixture (VA) in air was also calculated using the standard shunt equation (Comroe, Forster, Dubois, Briscoe, and Carlsen, 1962):

$\mathrm{VA} \%=\frac{\mathrm{O}_{2} \text { content of pulm. capillary blood }-\mathrm{O}_{2} \text { content of arterial }}{\mathrm{O}_{2} \text { content of pulm. capillary blood }-\mathrm{O}_{2} \text { content of mixed }}$ [venous blood

Oxygen content of arterial and pulmonary capillary blood was calculated by multiplying the amount of saturated haemoglobin by $1 \cdot 34$. The amount of oxygen in mixed venous blood was assumed to be 4 vol. $\%$ lower than in arterial blood (Strang and Macleish, 1961). The $\mathrm{S}_{\mathrm{a}} \mathrm{O}_{2}$ of pulmonary capillary blood was derived from the foetal blood $\mathrm{O}_{2}$-dissociation curve,

* Astrup micro-equipment type AME 1 and oxygen monitor type PHA 928 and $\mathrm{PO}_{2}$ electrode type E5044; Radiometer, Copenhagen, Denmark. assuming the $p \mathrm{H}$ and $\mathrm{Po}_{2}$ of capillary blood to be equal to the arterial $p \mathrm{H}$ and alveolar $\mathrm{Po}_{2}\left(\mathrm{P}_{\mathrm{A}} \mathrm{O}_{2}\right)$ respectively*. The $\mathrm{P}_{\mathrm{A}} \mathrm{O}_{2}$ was calculated from the alveolar air equation (Comroe et al., 1962):

$\mathrm{P}_{\mathrm{A}} \mathrm{O}_{2}=\mathrm{P}_{\mathrm{I}} \mathrm{O}_{2}-\mathrm{P}_{\mathrm{a}} \mathrm{CO}_{2} \times\left(\mathrm{F}_{\mathrm{I}} \mathrm{O}_{2}+\frac{1-\mathrm{F}_{\mathrm{I}} \mathrm{O}_{2}}{\mathrm{R}}\right)$.

$\mathrm{P}_{\mathrm{I}} \mathrm{O}_{2}$ and $\mathrm{F}_{\mathrm{I}} \mathrm{O}_{2}$ are the oxygen tension and concentration in the inspired air, and $\mathbf{R}$ is the respiratory quotient. The values of $\mathbf{R}$ published by Adams, Fujiwara, Spears, and Hodgman (1964) were used for premature infants and an $R$ value of 0.85 was assumed for adults.

\section{Results}

The main clinical features of the infants studied are summarized in Table $I$. There were no appreciable differences in birthweight and gestational age between the first and the second group, while in the third group the average birthweight was slightly higher. The average respiratory rate in the second and third group, and the Silverman's score in the third group, were higher than normal in the first two days of life and decreased gradually thereafter.

Samples from the right and left radial and temporal arteries, and the umbilical artery, have been analysed together because Moss et al. (1965) have found no appreciable right-to-left ductal shunts in similar infants.

Normal infants. The results obtained in the 40 normal premature infants are shown in Table II and in Fig. 1, 2, and 3; the data from normal adults are included for comparison.

The $p \mathrm{H}, \mathrm{P}_{\mathrm{a}} \mathrm{O}_{2}$, and $\mathrm{S}_{\mathrm{a}} \mathrm{O}_{2}$ at 3-5 hours of age were lower than later, but this age-group included only 4 subjects and allows no conclusions.

After 5 hours of life there were no appreciable

$\star$ When breathing air, the assumption that $\mathrm{P}_{\mathrm{A}} \mathrm{O}_{2}=\mathrm{PO}_{2}$ of pulmonary capillary blood may introduce an error in the calculation of VA; the latter may be overestimated and include the effect of a diffusion defect and/or of a ventilation/perfusion imbalance. 
TABLE II

Arterial Blood Values in 'Normal' Premature Infants Studied at Different Ages (Means $\pm S D$ )

\begin{tabular}{|c|c|c|c|c|c|c|c|c|c|c|}
\hline & & & 3-5 Hr. & 6-12 Hr. & 13-24 Hr. & 25-48 Hr. & 3-4 Dy. & 5-10 Dy. & 11-40 Dy. & Adults \\
\hline Number & . & $\cdots$ & 4 & 9 & 12 & 22 & 13 & 12 & 8 & 13 \\
\hline Age (mean) & $\cdots$ & $\cdots$ & $4 \mathrm{hr}$. & $8 \mathrm{hr}$. & $20 \mathrm{hr}$. & $35 \mathrm{hr}$. & $73 \mathrm{hr}$. & $7 \cdot 5 \mathrm{dy}$ & $27 \cdot 5 \mathrm{dy}$ & $30 \mathrm{yr}$. \\
\hline \multicolumn{2}{|c|}{$\mathrm{P}_{\mathrm{a}} \mathrm{O}_{2}(\mathrm{~mm} . \mathrm{Hg})$} & .. & $\begin{array}{l}59 \cdot 5 \ddagger \\
\pm 7 \cdot 7\end{array}$ & $\begin{array}{r}69 \cdot 7 \ddagger \\
\pm 11 \cdot 8\end{array}$ & $\begin{array}{r}67 \cdot 0 \ddagger \\
\pm 15 \cdot 2\end{array}$ & $\begin{array}{r}72 \cdot 5+ \\
\pm 20.9\end{array}$ & $\begin{array}{r}77 \cdot 8^{\star} \\
\pm 16 \cdot 4\end{array}$ & $\begin{array}{c}80 \cdot 3^{\star} \\
\pm 12 \cdot 0\end{array}$ & $\begin{array}{r}77 \cdot 8 t \\
\pm 9.6\end{array}$ & $\begin{array}{c}91 \cdot 8 \\
\pm 12 \cdot 4\end{array}$ \\
\hline $\mathrm{S}_{\mathrm{a}} \mathrm{O}_{2}(\%)$ & $\cdots$ & $\cdots$ & $\begin{array}{l}91 \cdot 3 \ddagger \\
\pm 1 \cdot 7\end{array}$ & $\begin{array}{l}95 \cdot 2 \ddagger \\
\pm 1 \cdot 2\end{array}$ & $\begin{array}{l}95 \cdot 3 \star \\
\pm 2 \cdot 1\end{array}$ & $\begin{array}{l}95 \cdot 0 \ddagger \\
\pm 2 \cdot 0\end{array}$ & $\begin{array}{l}95 \cdot 7 \dagger \\
\pm 1.5\end{array}$ & $\begin{array}{l}95 \cdot 1 \ddagger \\
\pm 1 \cdot 3\end{array}$ & $\begin{array}{l}96.0 \dagger \\
\pm 0.6\end{array}$ & $\begin{array}{l}97 \cdot 1 \\
\pm 1 \cdot 1\end{array}$ \\
\hline VA (\%) & . & .. & $\begin{array}{l}19 \cdot 5 \ddagger \\
\pm 4 \cdot 5\end{array}$ & $\begin{array}{l}14 \cdot 5 \ddagger \\
\pm 4 \cdot 8\end{array}$ & $\begin{array}{l}16 \cdot 3 \ddagger \\
\pm 6 \cdot 3\end{array}$ & $\begin{array}{l}13 \cdot 8 t \\
\pm 8 \cdot 7\end{array}$ & $\begin{array}{r}9 \cdot 8^{\star} \\
\pm 5 \cdot 5\end{array}$ & $\begin{array}{c}8 \cdot 2 \\
\pm 4 \cdot 5\end{array}$ & $\begin{array}{c}8 \cdot 4 \\
\pm 2.9\end{array}$ & $\begin{array}{l}5 \cdot 5 \\
\pm 5 \cdot 1\end{array}$ \\
\hline$p H$ & $\cdots$ & . & $\begin{array}{c}7 \cdot 329 \star \\
\pm 0.038\end{array}$ & $\begin{array}{c}7 \cdot 425 \\
\pm 0.072\end{array}$ & $\begin{array}{c}7 \cdot 464 \\
\pm 0.064\end{array}$ & $\begin{array}{c}7.434 \\
\pm 0.054\end{array}$ & $\begin{array}{c}7 \cdot 425 \\
\pm 0.044\end{array}$ & $\begin{array}{c}7 \cdot 378 \\
\pm 0.043\end{array}$ & $\begin{array}{c}7.425 \\
\pm 0.033\end{array}$ & $\begin{array}{c}7 \cdot 443 \\
\pm 0.044\end{array}$ \\
\hline $\mathrm{P}_{\mathrm{aCO}}$ (mm. $\mathrm{H}$ & $\mathrm{Hg})$ & .. & $\begin{array}{l}47 \cdot 3^{\star} \\
\pm 8 \cdot 5\end{array}$ & $\begin{array}{l}28 \cdot 2+ \\
\pm 6 \cdot 9\end{array}$ & $\begin{array}{l}27 \cdot 2+ \\
\pm 8 \cdot 4\end{array}$ & $\begin{array}{l}31 \cdot 3^{\star} \\
\pm 6 \cdot 7\end{array}$ & $\begin{array}{l}31 \cdot 7 \star \\
\pm 6 \cdot 7\end{array}$ & $\begin{array}{l}36 \cdot 4 \\
\pm 4 \cdot 2\end{array}$ & $\begin{array}{l}32 \cdot 9 \\
\pm 4 \cdot 0\end{array}$ & $\begin{array}{l}37 \cdot 9 \\
\pm 6 \cdot 4\end{array}$ \\
\hline $\mathrm{BE}(\mathrm{mEq} / 1)$. & . & .. & $\begin{array}{l}-3 \cdot 7 \ddagger \\
\pm 1 \cdot 5\end{array}$ & $\begin{array}{l}-4 \cdot 7 \ddagger \\
\pm 3 \cdot 1\end{array}$ & $\begin{array}{l}-3 \cdot 0 \ddagger \\
\pm 3 \cdot 3\end{array}$ & $\begin{array}{l}-2 \cdot 3 \ddagger \\
\pm 3 \cdot 0\end{array}$ & $\begin{array}{l}-2 \cdot 9 \ddagger \\
\pm 2 \cdot 3\end{array}$ & $\begin{array}{l}-3 \cdot 5 \ddagger \\
\pm 2 \cdot 3\end{array}$ & $\begin{array}{l}-2 \cdot 1 \ddagger \\
\pm 2 \cdot 2\end{array}$ & $\begin{array}{l}+1 \cdot 4 \\
\pm 1 \cdot 5\end{array}$ \\
\hline $\mathrm{Hb}(\mathrm{g} . / 100 \mathrm{ml}$ & & . & $\begin{array}{l}16 \cdot 2+ \\
\pm 1 \cdot 7\end{array}$ & $\begin{array}{l}16 \cdot 1+ \\
\pm 2 \cdot 8\end{array}$ & $\begin{array}{l}16 \cdot 0 \ddagger \\
\pm 2 \cdot 3\end{array}$ & $\begin{array}{r}15 \cdot 7 \ddagger \\
\pm 2 \cdot 4\end{array}$ & $\begin{array}{l}14 \cdot 3 \\
\pm 4 \cdot 8\end{array}$ & $\begin{array}{l}13 \cdot 3 \\
\pm 1 \cdot 8\end{array}$ & $\begin{array}{l}10.9 \\
\pm 3.0\end{array}$ & $\begin{array}{l}13 \cdot 0 \\
\pm 1 \cdot 1\end{array}$ \\
\hline
\end{tabular}

Values statistically different from adult controls: $\star=p<0.05, \quad t=p<0.01, \quad \neq=p<0.001$.

changes in $\mathrm{S}_{\mathrm{a}} \mathrm{O}_{2}$, except for a small increase at $11-40$ days. The values at all ages were significantly lower than in adult controls (Table II).

The $\mathrm{P}_{\mathrm{a}} \mathrm{O}_{2}$ in infants up to 40 days of age was also significantly lower than in adults (Table II); there was, however, a significant rise in $\mathrm{P}_{\mathrm{a}} \mathrm{O}_{2}$ from 6-24 hours to 3-10 days of life $(p<0.05)$.

Venous admixture in air (VA) during the first and second day of life was significantly greater than at 3-10 days $(\mathrm{p}<0.01$ and $\mathrm{p}<0.05)$.

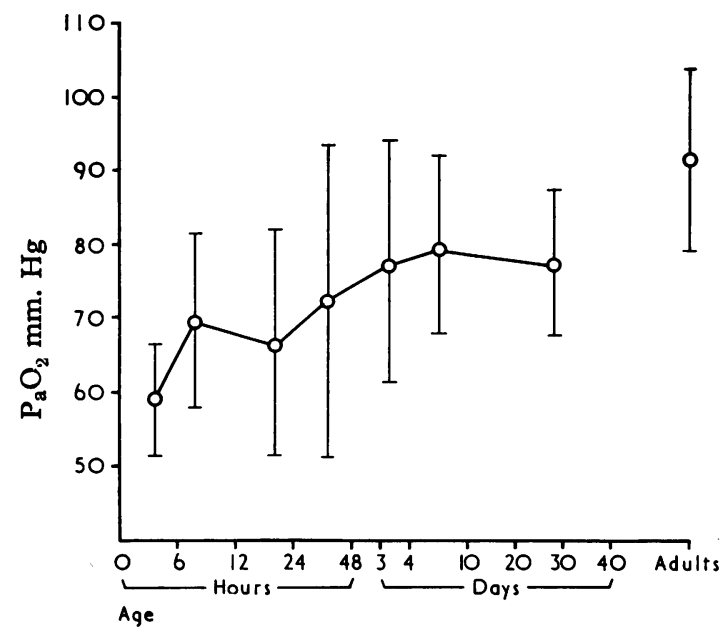

FIG. 1.-Mean ( $\pm S D$ ) arterial oxygen tension in 'normal' premature infants at different ages.
The base excess was always lower than in adults (Table II), but the $p H$ was similar, because the infants were hyperventilating relative to adults, in so far as the $\mathrm{P}_{\mathrm{a}} \mathrm{CO}_{2}$ at 6-24 and at 25-48 hours of life was significantly lower than in adults (Table II).

Infants with tachypnoea (Table III and Fig. 4 and 5). At 6-24 hours of life these babies had a significantly lower $\mathrm{P}_{\mathrm{a}} \mathrm{O}_{2}, \mathrm{~S}_{\mathrm{a}} \mathrm{O}_{2}$, and $p \mathrm{H}$, and a significantly higher $\mathrm{P}_{\mathrm{a}} \mathrm{CO}_{2}$ than normal prematures of the same age (Table III). VA was higher than normal, but not significantly so.

As in the normal group, there was an increase in $\mathrm{P}_{\mathrm{a}} \mathrm{O}_{2}$ and $\mathrm{S}_{\mathrm{a}} \mathrm{O}_{2}$ and a decrease in VA from 6-24 hours to 3-10 days of age ( $p<0.01)$.

Infants with mild respiratory distress (Table III and Fig. 4 and 5). The five prematures included in this group had a significantly lower than normal $\mathrm{P}_{\mathrm{a}} \mathrm{O}_{2}$ and $\mathrm{S}_{\mathrm{a}} \mathrm{O}_{2}$ and a higher $\mathrm{VA}$ at 6-24 hours of age. These abnormalities were still present on the second day of life, and disappeared thereafter. As in the other groups, the changes in $\mathrm{P}_{\mathrm{a}} \mathrm{O}_{2}, \mathrm{~S}_{\mathrm{a}} \mathrm{O}_{2}$, and VA from 6-24 hours to 3-10 days of age were statistically significant $(p<0 \cdot 01)$.

\section{Discussion}

The results of the present study are compared with data derived from previous publications in Table IV.

We have confirmed the presence of decreased arterial oxygenation in the newborn period in 


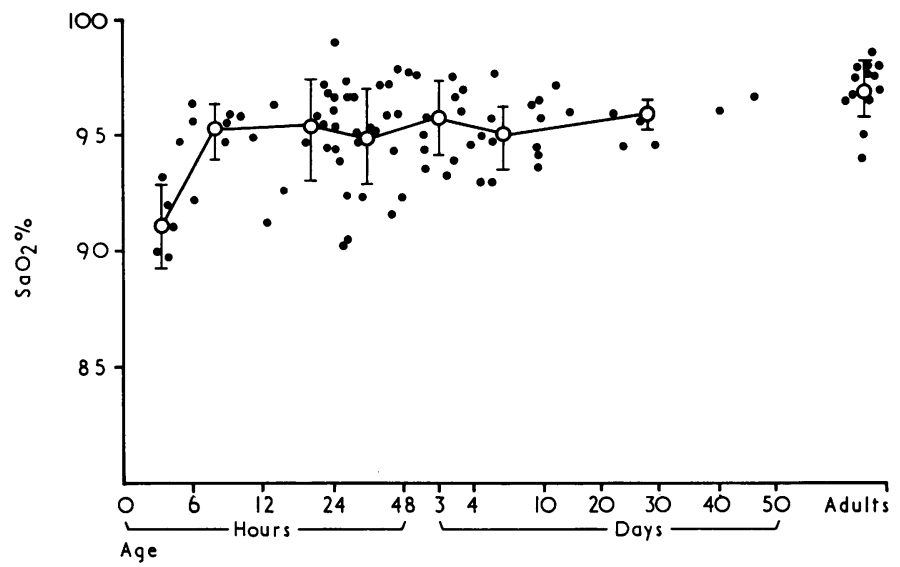

FIG. 2.-Arterial oxygen saturation in 'normal' premature infants of different ages. Means $\pm S D$ are shown.

'normal' premature infants and have found that the decrease in $\mathrm{P}_{\mathrm{a}} \mathrm{O}_{2}$ and $\mathrm{S}_{\mathrm{a}} \mathrm{O}_{2}$ is not generally greater than in full-term infants. Our data show that oxygen unsaturation persists in premature infants until the end of the first month.

After the first 5 hours of life alveolar hypoventilation cannot account for the low $\mathrm{P}_{\mathrm{a}} \mathrm{O}_{2}$ and $\mathrm{S}_{\mathrm{a}} \mathrm{O}_{2}$ in 'normal' premature infants, since the $\mathrm{P}_{\mathrm{a}} \mathrm{CO}_{2}$ remained below adult values. The presence of a large percentage of venous admixture in 'normal' premature infants implies the existence of one or more of three deficits of physiological function: a right-to-left shunt of blood, inequalities of ventilation to perfusion, or a diffusion defect. In the absence of studies during oxygen breathing it is impossible to be certain which of these deficits was

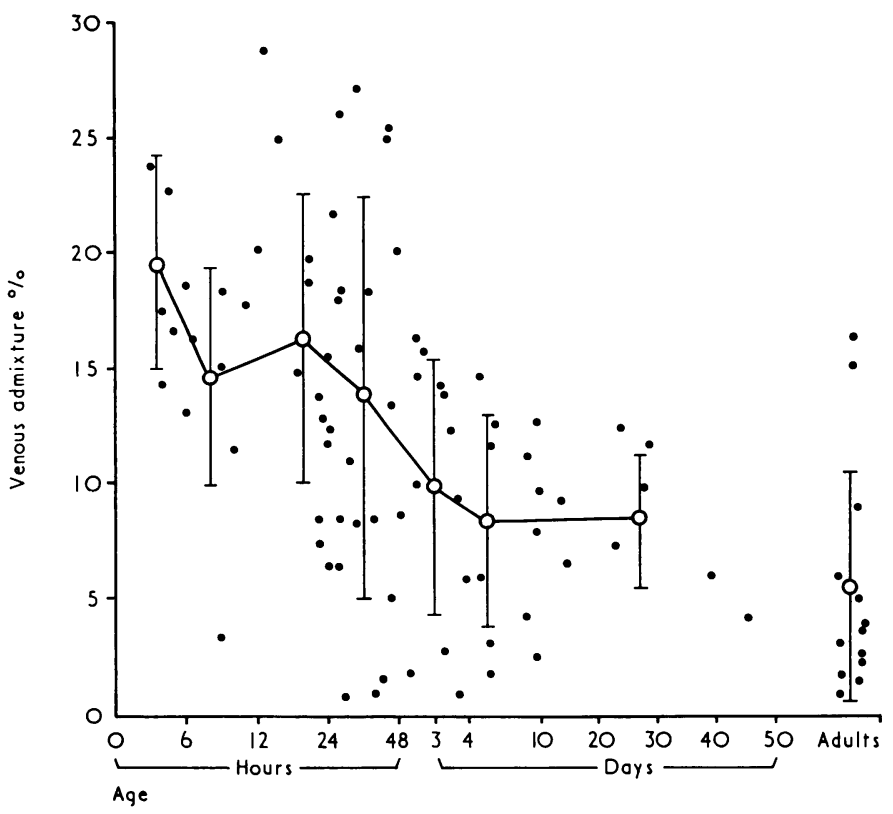

FIG. 3.-Venous admixture in air of arterial blood in 'normal' premature infants of different ages. Means \pm $S D$ are shown. 
TABLE III

Arterial Blood Values in 3 Groups of Premature Infants Studied at Different Ages (Means $\pm S D$ )

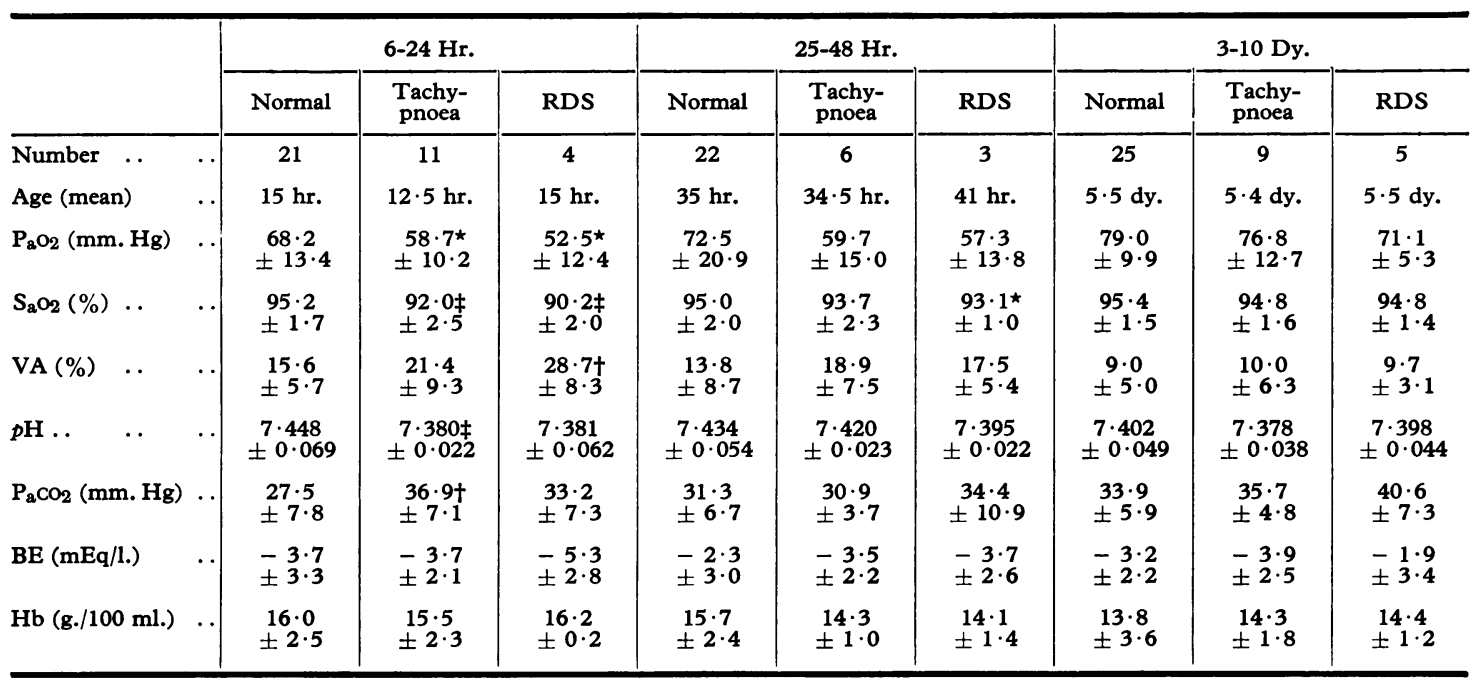

Values significantly different from 'normal' of the same age: $\star=p<0.05 ; \dagger=p<0.01 ; \ddagger=<0.001$.

present in the babies studied. Nelson and coworkers (1963) and Prod'hom and co-workers (1964) have demonstrated, in newborn infants with a higher birthweight, a large right-to-left shunt. On the other hand, from the data of Moss and coworkers (1965), it can be calculated that a true rightto-left shunt cannot account completely for the low $\mathrm{P}_{\mathrm{a}} \mathrm{O}_{2}$ and $\mathrm{S}_{\mathrm{a}} \mathrm{O}_{2}$ in premature infants breathing room air; this implies that a ventilation-perfusion imbalance (or possibly a diffusion defect) is also present.

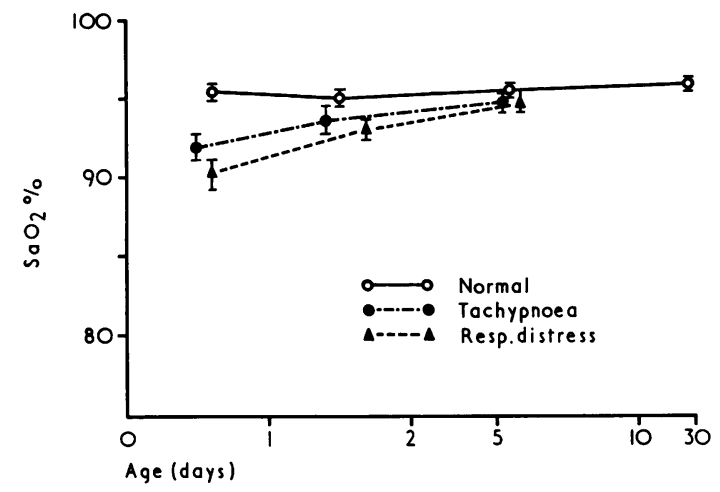

FIG. 4.-Arterial oxygen saturation at different ages in the 3 groups of premature infants studied. Means $\pm S E$ are shown.
The infants with tachypnoea were hypoventilating when compared with the normal prematures (the $\mathrm{P}_{\mathrm{a}} \mathrm{CO}_{2}$ was higher), and in addition their venous admixture was greater. These two changes account for the lower oxygen tension and saturation in these infants.

In the prematures with mild respiratory distress the venous admixture was greater than in either of the other groups, a finding that probably reflects a larger right-to-left shunt and also inequalities of ventilation and perfusion. As the arterial $\mathrm{PCO}_{2}$ was

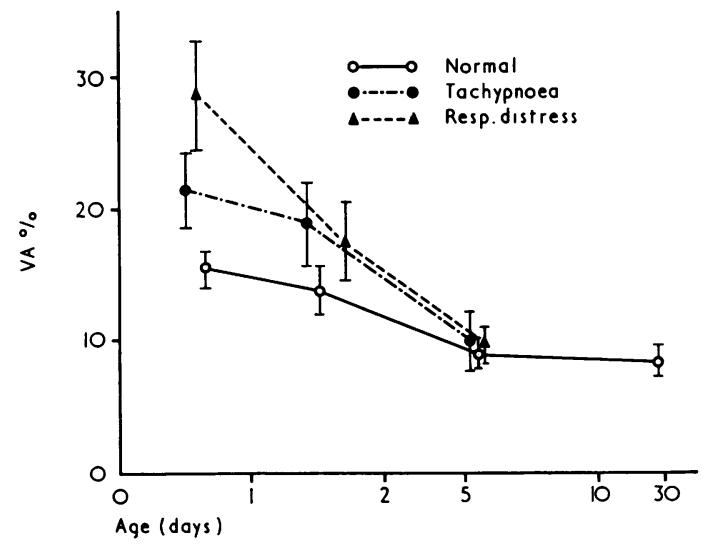

Fig. 5.-Venous admixture in air of arterial blood, at different ages, in the 3 groups of premature infants studied. Means $\pm S E$ are shown. 
TABLE IV

Comparison of Present Data with Those Found by Other Authors in Normal Full-term and Premature Newborn Infants

\begin{tabular}{|c|c|c|c|c|c|c|c|c|c|}
\hline Author & $\begin{array}{c}\text { Birthweight } \\
\text { (kg.) }\end{array}$ & $\begin{array}{l}\text { Gestation } \\
\text { (wk.) }\end{array}$ & No. & $\underset{\text { (hr.-dy.) }}{\text { Age }}$ & $\begin{array}{c}\mathrm{P}_{\mathrm{a}} \mathrm{O}_{2} \\
(\mathrm{~mm} \cdot \mathrm{Hg})\end{array}$ & $\begin{array}{l}\mathrm{S}_{\mathrm{a}} \mathrm{O}_{2} \\
(\%)\end{array}$ & $p \mathrm{H}$ & $\begin{array}{c}\mathrm{P}_{\mathrm{aCO}} \\
(\mathrm{mm} . \mathrm{Hg})\end{array}$ & $\begin{array}{l}\text { VA } \\
(\%)\end{array}$ \\
\hline $\begin{array}{l}\text { Stahlman (1947) } \\
\text { (Femoral artery) }\end{array}$ & $\begin{array}{c}3 \cdot 23 \\
(2 \cdot 50-4 \cdot 08)\end{array}$ & Full-term & $\begin{array}{r}8 \\
15 \\
11 \\
6\end{array}$ & $\begin{array}{c}16 \cdot 5 \mathrm{hr} . \\
(9-22) \\
34 \mathrm{hr} . \\
(29-48) \\
58 \mathrm{hr} . \\
(50-72) \\
82 \mathrm{hr} . \\
(75-96) \\
\end{array}$ & $\begin{array}{l}- \\
- \\
-\end{array}$ & $\begin{array}{l}93 \cdot 0 \\
94 \cdot 6 \\
94 \cdot 6 \\
92 \cdot 9\end{array}$ & $\begin{array}{l}7 \cdot 434 \\
7 \cdot 424 \\
7 \cdot 429 \\
7 \cdot 465\end{array}$ & $\begin{array}{l}30 \cdot 9 \\
31 \cdot 3 \\
30 \cdot 5 \\
29 \cdot 2\end{array}$ & $\begin{array}{l}- \\
- \\
-\end{array}$ \\
\hline $\begin{array}{l}\text { Weisbrot et al. (1958) } \\
\text { (Left atrium) }\end{array}$ & $2 \cdot 50$ & Full-term & $\begin{array}{r}7 \\
14\end{array}$ & $\begin{array}{l}3 \mathrm{hr} . \\
24 \mathrm{hr} .\end{array}$ & 二 & $\begin{array}{l}94 \cdot 7 \\
93 \cdot 2\end{array}$ & $\begin{array}{l}7 \cdot 341 \\
7 \cdot 408\end{array}$ & $\begin{array}{l}38 \cdot 3 \\
33 \cdot 6\end{array}$ & $=$ \\
\hline $\begin{array}{l}\text { Reardon et al. (1960) } \\
\text { (Temporal artery) }\end{array}$ & $\begin{array}{c}3 \cdot 15 \\
(2 \cdot 30-3 \cdot 90)\end{array}$ & Full-term & $\begin{array}{r}17 \\
6 \\
27 \\
6 \\
20 \\
7 \\
36 \\
6\end{array}$ & $\begin{array}{c}2 \cdot 6 \mathrm{hr} . \\
(1-4) \\
7 \cdot 0 \mathrm{hr} . \\
(4-10) \\
11 \mathrm{hr} . \\
(6-24) \\
38 \mathrm{hr} . \\
(30-45) \\
45 \mathrm{hr} . \\
(30-48) \\
97 \mathrm{hr} . \\
(76-112) \\
86 \mathrm{hr} . \\
(72-96) \\
5 \mathrm{dd} .\end{array}$ & $\begin{array}{c}- \\
85 \cdot 3 \\
- \\
78 \cdot 8 \\
- \\
87 \cdot 0 \\
- \\
-\end{array}$ & $\begin{array}{c}94 \cdot 9 \\
- \\
94 \cdot 1 \\
- \\
94 \cdot 4 \\
- \\
94 \cdot 5 \\
94 \cdot 9\end{array}$ & $\begin{array}{c}7 \cdot 306 \\
- \\
7 \cdot 368 \\
- \\
7 \cdot 386 \\
- \\
7 \cdot 379 \\
7 \cdot 390\end{array}$ & $\begin{array}{c}38 \cdot 3 \\
- \\
34 \cdot 4 \\
- \\
33 \cdot 9 \\
- \\
36 \cdot 3 \\
35 \cdot 2\end{array}$ & $\begin{array}{l}- \\
- \\
- \\
- \\
- \\
- \\
-\end{array}$ \\
\hline $\begin{array}{l}\text { Prod'hom et al. (1964) } \\
\text { (Umbilical artery) }\end{array}$ & $\begin{array}{c}3 \cdot 18 \\
(2 \cdot 27-4 \cdot 31)\end{array}$ & $\begin{array}{c}36 \cdot 5 \\
(35-39)\end{array}$ & $\begin{array}{l}20 \\
19 \\
14\end{array}$ & $\begin{array}{l}1 \mathrm{hr} . \\
4 \mathrm{hr} \\
24 \mathrm{hr} .\end{array}$ & $\begin{array}{l}61 \cdot 0 \\
72 \cdot 0 \\
71 \cdot 0\end{array}$ & $\begin{array}{l}- \\
\overline{-}\end{array}$ & $\begin{array}{r}7 \cdot 310 \\
7 \cdot 370 \\
7 \cdot 430 \\
\end{array}$ & $\begin{array}{l}46 \cdot 0 \\
40.0 \\
36.0 \\
\end{array}$ & $\begin{array}{l}31 \\
20 \\
20 \\
\end{array}$ \\
\hline $\begin{array}{l}\text { Moss et al. (1965) } \\
\text { (Ascending aorta) }\end{array}$ & $\begin{array}{c}2 \cdot 02 \\
(1 \cdot 36-2 \cdot 33)\end{array}$ & $?$ & $\begin{array}{r}6 \\
15 \\
20 \\
7\end{array}$ & $\begin{array}{c}9 \mathrm{hr} . \\
(2-12) \\
18 \mathrm{hr} \\
(13-24) \\
34 \mathrm{hr} \\
(25-48) \\
67 \mathrm{hr} . \\
(49-120)\end{array}$ & $\begin{array}{l}68 \cdot 5 \\
61 \cdot 3 \\
75 \cdot 9 \\
77 \cdot 7\end{array}$ & $\begin{array}{l}94 \cdot 0 \\
93 \cdot 5 \\
94 \cdot 7 \\
94 \cdot 3\end{array}$ & $\begin{array}{l}7 \cdot 376 \\
7 \cdot 391 \\
7 \cdot 394 \\
7 \cdot 356\end{array}$ & $\begin{array}{l}32 \cdot 7 \\
29 \cdot 8 \\
29 \cdot 3 \\
31 \cdot 9\end{array}$ & $\begin{array}{l}17 \\
16 \\
15 \\
11\end{array}$ \\
\hline $\begin{array}{l}\text { Present data } \\
\text { (Umbilical, temporal, and } \\
\text { radial artery) }\end{array}$ & $\begin{array}{c}1 \cdot 76 \\
(1 \cdot 26-2 \cdot 48)\end{array}$ & $\begin{array}{c}34 \cdot 5 \\
(28-40)\end{array}$ & $\begin{array}{r}4 \\
21 \\
22 \\
25 \\
8\end{array}$ & $\begin{array}{c}4 \mathrm{hr} . \\
(3-5) \\
15 \mathrm{hr} . \\
(6-24) \\
35 \mathrm{hr} . \\
(25-48) \\
5.5 \mathrm{dy} . \\
(3-10) \\
27.5 \mathrm{dy} . \\
(11-40)\end{array}$ & $\begin{array}{l}59 \cdot 5 \\
68 \cdot 2 \\
72 \cdot 5 \\
79 \cdot 0 \\
77 \cdot 8\end{array}$ & $\begin{array}{l}91 \cdot 3 \\
95 \cdot 2 \\
95 \cdot 0 \\
95 \cdot 4 \\
96 \cdot 0\end{array}$ & $\begin{array}{l}7 \cdot 329 \\
7 \cdot 448 \\
7 \cdot 434 \\
7 \cdot 402 \\
7 \cdot 425\end{array}$ & $\begin{array}{l}47 \cdot 3 \\
27 \cdot 5 \\
31 \cdot 3 \\
33 \cdot 9 \\
32 \cdot 9\end{array}$ & $\begin{array}{r}20 \\
16 \\
14 \\
9 \\
8\end{array}$ \\
\hline
\end{tabular}

normal (or even low) in these infants, hypoventilation was not a factor in the production of arterial oxygen unsaturation.

The results of this study are consistent with the view that right-to-left shunting of blood and maldistribution of gas with respect to blood flow are common in premature infants, and may persist throughout the first month of life. When the infants are asymptomatic these abnormalities do not seem greater than in full-term infants, but in the presence of clinically apparent symptoms (tachypnoea or mild respiratory distress, even with normal chest $x$-ray films) more severe derangements of function are present.

\section{Summary}

Arterial oxygen and carbon-dioxide tension $\left(\mathrm{P}_{\mathrm{a}} \mathrm{O}_{2}\right.$ and $\left.\mathrm{P}_{\mathrm{a}} \mathrm{CO}_{2}\right), p \mathrm{H}$, base excess, and $\mathrm{Hb}$ concentration were measured in 59 premature infants from 3 hours to 40 days of age and in 13 normal adults; oxygen saturation $\left(\mathrm{S}_{\mathrm{a}} \mathrm{O}_{2}\right)$ and venous admixture in air (VA) were also calculated. The babies were divided into 3 groups.

In a group of 40 'normal' prematures $\mathrm{S}_{\mathrm{a}} \mathrm{O}_{2}$ did not change appreciably after 5 hours of age, whereas there was a significant rise in $\mathrm{P}_{\mathrm{a}} \mathrm{O}_{2}$ and a fall in VA from 6-24 hours to 3-10 days of life. $\mathrm{P}_{\mathrm{a}} \mathrm{O}_{2}$ and $\mathrm{S}_{\mathrm{a}} \mathrm{O}_{2}$ at all ages were significantly lower than in normal adults. 
A group of 14 prematures with tachypnoea had significantly lower $\mathrm{P}_{\mathrm{a}} \mathrm{O}_{2}$ and $\mathrm{S}_{\mathrm{a}} \mathrm{O}_{2}$ and higher $\mathrm{P}_{\mathrm{a}} \mathrm{CO}_{2}$ at 6-24 hours of life when compared to normal prematures of the same age.

A third group of 5 prematures who showed mild transient respiratory distress had lower than normal $\mathrm{P}_{\mathrm{a}} \mathrm{O}_{2}$ and $\mathrm{S}_{\mathrm{a}} \mathrm{O}_{2}$ and higher VA at 6-24 hours of age. These abnormalities were still present on the second day of life.

The significance and the implications of these findings have been discussed.

\section{REFERENCES}

Adams, F. H., Fujiwara, T., Spears, R., and Hodgman, J. (1964). Gaseous metabolism in premature infants at $32-34^{\circ} \mathrm{C}$. ambient temperature. Pediatrics, 33, 75 .

Adamsons, K., Jr., Daniel, S. S., Gandy, G., and James, L. (1964). Influence of temperature on blood $\mathrm{pH}$ of the human adult and newborn. f. appl. Physiol., 19, 897.

Astrup, P., Jörgensen, K., Siggaard Andersen, O., and Engel, K. (1960). The acid-base metabolism: a new approach. Lancet, $1,1035$.

Bradley, A. F., Stupfel, M., and Severinghaus, J. W. (1956). Effect of temperature on $\mathrm{PCO}_{2}$ and $\mathrm{Po}_{2}$ of blood in vitro. $\mathcal{F}$. appl. Physiol., 9, 201.

Bucci, G., Scalamandrè, A., Savignoni, P. G., Orzalesi, M., and Mendicini, M. (1966). Crib-side sampling of blood from the radial artery. Pediatrics, 37, 497.

Comroe, J. M., Forster, R. E., Dubois, A. B., Briscoe, W. E., and Carlsen, E. (1962). The Lung, 2nd ed. The Year Book Publishers, Chicago.

Edwards, M. J., and Ross, B. B. (1959). Graphical representation of respiratory gas dissociation characteristics of fetal and maternal blood. f. appl. Physiol., 14, 454.

Graham, B. D., Koeff, S. T., Tsao, M. U., Sloan, C., and Wilson, J. L. (1959). Direct plasma oxygen tension determination in infants and adults in air and in modified atmospheres. Amer. F. Dis. Child., 98, 593.

- Reardon, H. S., Wilson, J. L., Tsao, M. U., and Baumann, M. L. (1950). Physiologic and chemical response of premature infants to oxygen-enriched atmospheres. Pediatrics, 6, 55.

Iannaccone, G., Bucci, G., and Savignoni, P. G. (1965). Diagnostic and prognostic value of $\mathrm{X}$-ray findings in respiratory distress syndrome of newborn premature infants. Ann. Radiol., 8, 237.

Moss, A. J., Emmanouilides, G. C., Rettori, O., Higashimo, S. M., and Adams, F. H. (1965). Postnatal circulatory and metabolic adjustments in normal and distressed premature infants. Biol. Neonat. (Basel), 8, 177.
Nelson, N. M., Prod'hom, L. S., Cherry, R. B., Lipsitz, P. J., and Smith, C. A. (1963). Pulmonary function in the newborn infant: the alveolar-arterial oxygen gradient. $\mathcal{F}$. appl. Physiol., 18, 534.

$\longrightarrow,-$, , and Smith, C. A. (1964). A further extension of the in vivo oxygen-dissociation curve for the blood of the newborn infant. F. clin. Invest., 43, 606.

Oliver, T. K., Jr., Demis, J. A., and Bates, G. D. (1961). Serial blood-gas tensions and acid-base balance during the first hour of life in human infants. Acta paediat. (Uppsala), 50, 346.

Prod'hom, L. S., Levison, H., Cherry, R. B., Drorbaugh, J. E., Hubbell, J. P., Jr., and Smith, C. A. (1964). Adjustment of ventilation, intrapulmonary gas exchange, and acid-base balance during the first day of life. Normal values in well infants of diabetic mothers. Pediatrics, 33, 682.

Rahn, H., and Fenn, W. O. (1955). A Graphical Analysis of the Respiratory Gas Exchange: The $\mathrm{O}_{2}-\mathrm{CO}_{2}$ Diagram. American Physiological Society, Washington.

Reardon, H. S., Baumann, M. L., and Hadded, E. J. (1960). Chemical stimuli of respiration in the early neonatal period. F. Pediat., 57, 151.

Scalamandrè, A., Bucci, G., Orzalesi, M., Mendicini, M., and Savignoni, P. G. (1966). Metodi per lo studio dell'equilibrio acido-base e dell'ossigeno nel sangue arterioso del neonato. Arch. ital. Pediat., 24, 47.

Siggaard Andersen, O. (1962). The $\mathrm{pH}-\log \mathrm{PcO}_{2}$ blood acid-base nomogram revised. Scand. F. clin. Lab. Invest., 14, 598.

Silverman, W. A., and Andersen, D. M. (1956). A controlled clinical trial of effects of water mist on obstructive respiratory signs, death rate and necropsy findings among premature infants. Pediatrics, 17, 1.

Stahlman, M. T. (1957). Pulmonary ventilation and diffusion in the human newborn infant. $\mathcal{F}$. clin. Invest., 36, 1081.

Strang, L. B., and Macleish, M. H. (1961). Ventilatory failure and right-to-left shunt in newborn infants with respiratory distress. Pediatrics, 28, 17.

Weisbrot, I. M., James, L. S., Prince, C. E., Holaday, D. A., and Apgar, V. (1958). Acid-base homeostasis in the newborn infant during the first 24 hours of life. $\mathcal{F}$. Pediat., 52, 395.

\section{Addendum}

After this paper was accepted Thibeault, Clutario, and Auld (1966) found similar results to ours.

\section{REFERENCE}

Thibeault, D. W., Clutario, B., and Auld, P. A. M. (1966). Arterial oxygen tension in premature infants. F. Pediat., 69, 449. 